\title{
The rise of China-challenges and opportunities for the European Union
}

\author{
Thomas Christiansen $^{1,2} \cdot$ Richard $^{\text {Maher }^{2}}$
}

Published online: 4 April 2017

(C) The Author(s) 2017. This article is published with open access at Springerlink.com

\begin{abstract}
China's growing power and influence raise important and inescapable questions for countries and societies around the world, not least for Europe. A rising China offers opportunities for greater cooperation, both bilaterally and in the context of old and new multilateral institutions, yet also carries inherent risks for the European Union (EU), not least in the way in which it may make it (even) more difficult to manage the relations with other global powers while also maintaining unity among EU member states. This special issue examines Europe's response to the steady and dramatic rise of China over the past two decades. In particular, it explores the challenges as well as the many instances of engagement that define their relations today across a number of policy areas, including economic, diplomatic, and security relations. The contributions to this special issue demonstrate the varied, multi-faceted and to some extent contradictory nature of EU-China relations. The two sides are in an ever-closer economic embrace, yet they remain distant and occasionally antagonistic with respect to security concerns or normative discourses.
\end{abstract}

\section{Introduction}

China's growing power and influence are reshaping Asian security, the global economy, and the structure and dynamics of global governance in important and lasting ways. The nature, direction, and implications of these developments are a matter of debate

Thomas Christiansen

t.christiansen@maastrichtuniversity.nl

Richard Maher

richard.maher@eui.eu

1 Department of Political Science, Maastricht University, Grote Gracht 90-92, NL-6211

SZ Maastricht, the Netherlands

2 Robert Schuman Centre for Advanced Studies, European University Institute, Via Boccaccio 121, Florence 50013, Italy 
among many scholars and observers, but what is beyond doubt is that China's rise raises urgent and inescapable questions for countries and societies around the world, not least for Europe. ${ }^{1}$

This special issue examines Europe's response to the steady and dramatic rise of China over the past two decades. In particular, it explores the challenges as well as the many instances of engagement that mark their relations today in a variety of realms, be it economic, diplomatic, or security.

For the European Union - institutions, national governments, businesses, and other actors - prominent and pertinent questions include: Which of their interests and priorities are most affected by China's growing power and influence? What are the possible benefits as well as the potential risks of China's rise? How should Europe position itself to reap the gains while avoiding the perils of China's expanding capabilities and aspirations? And how are the EU's relations with other powers such as the USA or Russia affected by and affecting its response to the rise of China? This special issue seeks to answer these and related questions.

For the foreseeable future, China's clout and its ability to shape and influence international outcomes will continue to increase. While China's rise offers greater opportunities for trade and investment and greater resources to address common global challenges, it has also fostered anxiety and feelings of uncertainty in some countries, such as over China's future intentions vis-à-vis its neighbours and how Beijing will use its greater leverage in regional and international settings. The Chinese development model combines rapid industrialization with political authoritarianism and military modernization. Its ambitions - from the East and South China Seas as well as further beyond its borders - seem to be expanding along with its material capabilities. While some doubt whether China can be fully incorporated into an open, rules-based international world order, the Chinese leadership has declared its strong commitment to economic globalization, multilateralism, and international regimes (Xi 2017).

EU-China relations have become more intensive and extensive over the past three decades. The EU and China announced a "comprehensive strategic partnership" in 2003 that was intended to elevate their relationship from the economic to the political and even security domains. For Europe, a comprehensive strategic partnership with China would support Beijing's integration into the existing international order and shows that the EU was ready for a greater leadership role in global affairs. For China, the partnership was intended to facilitate its economic modernization and development, enhance its "comprehensive" national power, especially through technology transfers with European firms, bolster the regime's legitimacy and stability, and facilitate the emergence of a multipolar international system. Even if that "strategic partnership" has not lived up to expectations (Maher 2016a), it has facilitated much greater and deeper contacts between EU and Chinese officials across many different policy domains, including economic, diplomatic, and even security (Christiansen 2015).

Trade and investment between China and Europe have grown dramatically over the past two decades. Aggregate trade between the EU and China surpassed $€ 514$ billion in 2016, up from $€ 260$ billion in $2006{ }^{2}$ Bilateral Europe-China investment (both portfolio

\footnotetext{
${ }^{1}$ The literature on the causes and consequences of China's growing economic and military power is now voluminous. See Shambaugh 2013; Helleiner and Kirshner 2014; Christensen 2015.

2 http://trade.ec.europa.eu/doclib/docs/2006/september/tradoc_113366.pdf
} 
and foreign direct) has also increased. Chinese investment in Europe, for example, hit a record high in 2015. Chinese direct investment, while still accounting for a small portion of total incoming foreign direct investment (FDI) in Europe, grew by $37 \%$ in 2015 (Jones 2016). ${ }^{3}$

Despite nearly a decade of sluggish growth, stubbornly high unemployment in many of its member states, the ongoing sovereign debt and banking troubles in the Eurozone, and the prospect of BREXIT, the EU remains the world's biggest single market. As such, China is looking to upgrade and modernize land and maritime trade routes to further expand trade opportunities with Europe and other countries along the old "Silk Road". China's proposed New Silk Road would connect China with Europe, creating a huge economic space. China is also investing in port facilities for its planned Maritime Silk Road, and the China-led Asian Infrastructure Investment Bank (AIIB) is intended to provide finance for related infrastructure projects. China aims to become a "moderately prosperous" country by 2020 and is dependent on global stability and trade liberalization to realize this goal.

Diplomatic and political relations between the EU and China have broadened and deepened. There is now an annual EU-China summit, in which the EU is represented by the President of the European Council and the President of the European Commission, and China is represented at the level of Prime Minister. There are also eight ministerial dialogues, including an annual High Level Strategic Dialogue and High Level Economic and Trade Dialogue (HED). And there are now 51 sectoral dialogues that cover virtually every policy area that affects the relationship, including human rights, intellectual property, science and technology cooperation, consumer protection, climate change, and migration and mobility. ${ }^{4}$

Even in security affairs - long the policy area in which coordination has been weakest - there are now concrete examples of EU-China cooperation, including in the areas of nuclear proliferation, counterterrorism, and cyber attacks, even though cooperation in these areas remains difficult (Kirchner et al. 2016). The EU and China coordinate actions in anti-piracy operations in the Gulf of Aden off the coast of Somalia, and their cooperation were important in the P5 +1 negotiations over Iran's nuclear program.

In the following, we briefly look at two sets of key areas - economic relations and global governance, on the one hand, and security and geo-politics, on the other-which are being discussed in greater depth in the contributions to this special issue. In each case, we highlight some of the key issues facing the EU.

\section{Economic relations and global governance}

The deep economic engagement between Europe and China over the past two decades means that in the mid-2010s their economic fates have become strongly interlinked. The EU is the top destination for Chinese exports and, after the USA, the second biggest supplier of goods to China. Between 2005 and 2016, according to the China Global Investment Tracker, China invested more than \$200 billion in Europe,

\footnotetext{
${ }^{3}$ See also http://rade.ec.europa.eu/doclib/docs/2016/april/tradoc_154472.pdf

${ }^{4}$ See http://strategicpartnerships.eu/pays/eu-china/
} 
compared to $\$ 134$ billion in the USA. Millions of jobs in both Europe and China depend on this growing trade and investment relationship. As China's economic rise continues and Europe and China become more economically interdependent, the following three questions have become particularly important:

First, how will the EU and China manage their economic relationship and in particular the frictions and tensions that are bound to emerge as the two sides increasingly produce goods and services of high added value and technological know-how? The IMF said in its annual China report in August 2016 that China's "economic transition will continue to be complex, challenging, and potentially bumpy." Exports, investments in industry, and an expanding labour force have propelled China's growth over the past three decades. The old sources of economic growth are no longer generating the same rates of return, however. China will need new sources of growth in the years ahead, and Chinese leaders are trying to fashion a more sustainable growth strategy. China is moving away from the export of lost-cost manufactured goods and moving up the value-added chain, putting Chinese firms in direct competition with European businesses.

The rising competitiveness of Chinese manufacturers, but also instances of Chinese over-capacity and subsequent allegations of dumping goods in world markets, have led to frequent confrontations between authorities on either side. This is exemplified by the fact that of the European Commission's 39 ongoing anti-dumping investigations, China is the target of 29 of them. ${ }^{5}$ European governments and businesses often complain that China has still not opened up fully its economy to investment from European firms and businesses. China continues to place restrictions on foreign investment in many sectors of its economy. European governments and companies are calling for reciprocity in China, especially over government procurement projects. Some Europeans are questioning whether a balanced and mutually beneficial economic relationship with China is even possible, and it is in this context that the EU has had to face pressure from China to grant its market economy status (MES) under the terms of its accession to the World Trade Organization. The EU and China are also involved in ongoing negotiations to conclude a bilateral investment agreement (BIT).

A second question concerns the impact of China's economic activities in Europe. Chinese firms, many either state owned enterprises (SOEs) or statefunded, are pursuing a range of investments in Europe and joint ventures with European firms. Chinese direct investment in Europe, while still modest as a share of Europe's overall share of inward direct investment, has been rising steadily over the past decade, and rapidly in the aftermath of the financial crisis that started in 2009. One consulting group estimates that Chinese overseas assets will go from $\$ 6.4$ trillion today to almost $\$ 20$ trillion by 2020 (Anderlini 2015). Europe is a mature market and offers many safe and attractive investment opportunities for Chinese SOEs. Across Europe, Chinese firms initially invested heavily in infrastructure projects such as ports and airports, the energy sector, telecommunications, and real estate. More recently, however, acquisitions have focused on hightech companies in sectors such as robotics, semi-conductors, and chemicals. As a result, there have been concerns about the transfer of know-how and critical expertise from Europe to China and the loss of competitive advantage that Europe

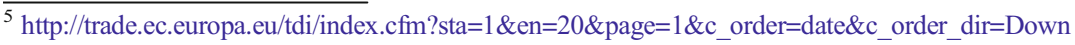


might face as a result. The experience of the developments in the photovoltaic sector-where Europe lost a dominant market position to China following a number of key acquisitions - is a reminder of such future threats.

Consequently, European governments have become wary over Chinese investments into sensitive areas of their economies. Yet, Europe is badly positioned to address these concerns. Unlike the USA and Australia, the EU has no regulatory body that scrutinizes foreign investments, nor is there as yet a dedicated industrial policy to protect and maintain European ownership of strategic firms and sectors. In fact, due to the constraints put on EU member states through its state aid policy, national governments are uniquely hamstrung in seeking to ward off unwelcome take-overs through public intervention.

A third point concerns China's role in global financial governance. China has made various initiatives to reform Bretton Woods institutions such as the IMF and World Bank. Everyone acknowledges that these institutions must reform to reflect current global economic realities. China was not involved when these global norms, and institutions were set up in the aftermath of WWII by Western powers. In order to accommodate Chinese demands, pressure will mount on European states (as well as on the USA and Japan) to cede more voting authority in institutions like the IMF and World Bank. In 2016, the IMF included the renminbi (RMB) within its Special Drawing Rights (SDR), which will lead to the euro being a slightly less important global reserve currency. It remains to be seen how Europe will react to the threat of losing further weight and influence in these bodies - a sensitive issue not least in the context of the IMF's critical involvement in the Eurozone bail-outs.

At the same time, China has been busy constructing alternative financial institutions, both in the context of the BRICS with the New Development Bank (Maihold 2014) or in wider regional frame with the AIIB (Renard 2015). China's overall stake in the AIIB is $30 \%$, and its voting share is $26 \%$, endowing it with the power to veto projects. While there is a regional development angle that countries in Central Asia will welcome, it is also seen as a vehicle for China to advance its strategic vision of "One Belt, One Road" (OBOR), thus cementing the centrality of China in future trade relations between Europe and Asia. This development of alternative economic governance structures is extended further if the Regional Comprehensive Economic Partnership (RCEP) - a free trade agreement under negotiation among the ASEAN Plus Six countries-receives a boost after the failure of the Trans-Pacific Partnership (TPP).

Evidently, while mutual trade and investment continue to be the cornerstones of EUChina relations, the situation is becoming more complex and challenging. As the leading export-oriented economies in the world, the two sides are mutually dependent on each other, and on a functioning and open global economy. Yet, not only are global conditions for liberal trade increasingly adverse, but also bilaterally there are increasingly obstacles that both sides need to address. All this occurs in the context of "domestic" difficulties in Europe: concerns over Greek sovereign debt, liquidity of financial institutions, and the anticipated impact of BREXIT on the European economy - not an ideal environment for the EU to be addressing the challenges posed by China in the economic and financial realm (Christiansen, Kirchner and Wissenbach 2017, The European Union and China, unpublished). 


\section{Security and geopolitics}

Compared to their rapidly growing trade and investment relationship, cooperation between China and the EU on regional and global security issues remains limited. The EU (and even large member states such as France and Germany) and China are regional actors located in different global regions. Europe has few direct strategic claims or interests in the Asia-Pacific, and China has few in Europe. Still, a number of issues are central to Europe's response to China's rise in the security and geopolitical domains. In particular, the following three questions need to be addressed.

The first question is: How is Europe responding to the changing security environment in the Asia-Pacific? China's military spending has risen by an average of $9.5 \%$ per year over the past decade, and its military budget for 2015 is estimated to be between $\$ 145$ and \$215 billion. Over the past decade, Beijing has made major investments in advanced weaponry, communications, surveillance, and other military technology (Office of the Secretary of Defense 2015). The People's Liberation Army (PLA) has shifted its emphasis from ground forces to air, naval, space, and cyber forces. As one analysis puts it, China's military forces "now boast advanced ballistic missiles, various types of cruise missiles, nuclear submarines, modern surface ships, and an aircraft carrier; as well as additional advancements in the emerging areas of space, cyber, and the electromagnetic spectrum" (Moore and Berreda 2016).

China's actions in the East and South China Seas are a cause of concern and anxiety for many countries in the region. Some countries are pushing back against China's "island building" activities, and its pursuit of military, fishing, and mineral-exploitation rights in the South China Sea and tensions are likely to remain even if China has been deft at defusing opposition through its "chequebook diplomacy" in the region (Financial Times 2016). In addition to the various maritime disputes, other possible flash points exist in East Asia and the western Pacific, including the future status of Taiwan and North Korea's erratic behaviour.

European states only have a limited military presence in the Asia-Pacific, giving little ability to shape security dynamics directly. Instead, Europe has positioned itself as a diplomatic broker on issues such as counterterrorism, maritime cooperation, preventive diplomacy, and disaster management. Europe has sought to strengthen regional multilateral institutions and to enhance and expand diplomatic mechanisms to avoid costly miscalculation. In particular, it has emphasized the need for dialogue and the rule of international law, not least with respect to the ruling from the Permanent Court of Arbitration in the South China Sea case between the Philippines and China.

Second, arms sales and advanced technology transfers continue to be a point of contention between Europe and China. The EU arms embargo on China, imposed after the 1989 Tiananmen Square crackdown, continues to be a particularly sore spot in the relationship, even if in recent years the Chinese leadership has toned down its complaints about the ban. The UK, reflecting US preferences, has been one of the biggest opponents of lifting the arms embargo, which has long since mutated from a humanitarian gesture to a security policy. One consequence of the UK's exit from the EU may be a renewed push by countries such as France and Spain that favour lifting the embargo (Bräuner et al. 2015, 15-37).

A third issue is how Europe responds to the future of US-China relations. The SinoAmerican relationship has been growing more antagonistic in recent years as the USA 
has viewed the Chinese military build-up and its assertive stance in the East and South China Seas as a threat to its allies and to regional stability more generally. China, in return, has viewed President Obama's "pivot" to the Asia-Pacific with suspicion, indeed as an attempt at containment, something that many in Washington would agree with (and applaud). Given President Trump's belligerent discourse in general and his complaints about China in particular, one may well expect the relationship to get more rocky in the future, even though the already high degree of interdependence between the two economies provides powerful incentives to avoid conflict and to manage the inevitable tensions and disagreements that arise. Ironically, Trump's decision to abandon the TPP - a cornerstone of Obama's pivot (and hence a key element in the containment of China)-removes an important obstacle for Chinese economic expansion in the Asia Pacific. It also creates new opportunities for the EU to become more active in the region.

In this regard, it is important to note how European and US attitudes and interests toward China diverge in many respects (Maher 2016b). While from an American perspective, China is generally seen as more of a rival, if not as an outright threat, whose expansion needs to be "balanced," for Europe China is more often regarded as an opportunity and a partner. This is true both for the EU as a whole (as demonstrated by the above-mentioned policy of strategic partnership) as it is for individual member states such as the UK (BBC 2015), Germany (Nicholson 2015), or the countries of Central and Eastern Europe (Sieren 2014). Given its limited security relations with China and its deep economic interdependence, Europe's attitude towards the rise of China are fundamentally different from those of the USA. The question is, How the EU will manage to bridge this difference in the light of the strong and valued transatlantic relationship?

\section{Contributions to this special issue}

The contributions to this volume discuss specific aspects of this relationship in their historical, political, and theoretical contexts. As the articles show, China's rise holds important implications for both the conduct and the study of EU-China relations. China's rise is politically important because it is shaping international politics in deep and fundamental ways, including the economic and security environments Europe faces. China's rise is theoretically important because it is opening up new agendas and questioning old assumptions about the study of Europe's role in the world.

The papers in this special issue also highlight the range of challenges and choices confronting Europe over how it should respond to China's rise, including the ways in which Europe is embracing but also resisting China's power and influence, especially in the economic sphere. The articles highlight China's impact on European politics and integration; and how or to what extent Europe can shape China's choices as it continues to expand its power and influence?

The articles in this special issue also show how the Europe-China relationship is constantly evolving. This is a result of changes within Europe, China, and the international system itself. Europe's internal turmoil - from the UK vote to leave the EU, the ongoing problems within the Eurozone, and the seemingly interminable refugee crisis-affects its capacity and even its willingness to act in a coherent and unified 
manner. And as China seeks to restructure its economy, maintains its internal political and social cohesion, and gets accustomed to its greater regional and global role, how will it (re)define its interests and priorities?

Richard Maher (Maher 2017) asks how Europe should respond to China's growing economic and military capabilities and to the more assertive foreign policy behaviour it has generated. Should Europe seek to check or even resist China's rise, or should it instead rely on a strategy of engagement and accommodation? Maher identifies and outlines three distinct and coherent strategic visions that could guide Europe's policy and strategy toward China and the Asia Pacific over the next 10 to 15 years: balancing, engagement, and retrenchment. Maher's article concludes by examining what might prompt Europe to pursue a clearer and more consistent strategic approach toward China in the years ahead.

The following two contributions consider Europe's response to the rise of China in the context of relations with other key powers, namely the USA and Russia. The article by Le Corre and Pollack (Le Corre and Pollack 2017) explores whether Europe and the USA can more closely coordinate their approaches to China's growing economic power and political influence. They note that Europe and the USA share a number of concerns regarding China's rise, but their separate identities and interests also reveal significant differences, which impedes their efforts to forge a more coherent approach toward Beijing. European and American policy coordination will be essential to any successful incorporation of China within a rules-based international order, they note, but the prospects will depend heavily on the Trump Administration's willingness to commit to full consultations with the EU on these issues.

Bjørnar Sverdrup-Thygeson's (Sverdrup-Thygeson 2017) article investigates U.S. and Russian influence on EU policy toward China. Europe faces a dilemma in the formulation and pursuit of its diplomatic approach toward China. It must balance relations with the USA, its most important ally and key security provider, with a fastgrowing China, the USA's rising strategic competitor in the Asia Pacific. While U.S. interests and concerns directly shape European policy toward China, Russia's impact on European policy is more indirect. But by influencing the EU's security priorities in Europe's "near abroad," Sverdrup-Thygeson shows how Russia may also shape the EU's capabilities and motivations to press forward with a diplomatic offensive towards China and Asia more broadly.

Having looked at these global and strategic issues facing the Sino-European relationship, the special issue turns to the political economy dimension of these relations. James Reilly (Reilly 2017) examines China's economic statecraft in Europe. He identifies three strategies China has pursued towards European countries, each of which is designed to advance a specific type of policy objective: specific reciprocity, diffuse reciprocity, and strategic engagement. Comparing these three strategies through China's efforts to discourage European leaders from meeting the Dalai Lama, secure market economy status and Beijing's response to Europe's post-2009 financial crisis, Reilly shows how the tensions between a reciprocity and an engagement strategy have undermined China's efforts to reassure Europeans of its benevolent intentions.

Duncan Freeman (Freeman 2017), in his contribution, considers the complexity of economic relations between the EU and China. Starting with the recognition that the Chinese economy is undergoing a fundamental transformation, involving not only a slow-down in GDP growth, but also a structural transition, Freeman points out that this 
rapid change will have a diverse, and indeed redistributive, impact on the member states of the European Union: the "new normal" stage in the rise of China will have both winners and losers on the European side of this important trade relationship.

Camille Brugier's (Brugier 2017) article examines another facet of EU-China trade, namely the linkage between trade and human rights. In particular, she notes differences in the European and U.S. approach to China on the issue of human rights. Whereas the Europeans generally do not publicize China's human rights record, U.S. policy is based on a close linkage between trade negotiations and human rights. She argues that the American approach has not yielded many positive results and has in fact pushed China to trade more with the EU. Brugier also notes how one of China's prime interests in trade with the EU is the transfer of expertise, not solely of technology. The EU approach, she argues - based on a separation of trade and human rights, a willingness to negotiate bilaterally in trade disputes and the EU's expertise in areas now high in demand in China - is what makes the EU China's top trade partner.

Jean-Christophe Defraigne's (Defraigne 2017) contribution is concerned with the changing nature of Chinese investment policy in Europe and the implications that this might have for the EU. He charts the increasing diversification of Chinese firms to the higher echelons of the value chain through acquisitions in Western economies and the development of a Chinese industrial policy involving overseas investment into strategic assets - a trend that has met some resistance in the USA but less so in Europe. Since the onset of the economic and financial crisis in 2009, there have been greater opportunities for Chinese investments in Europe, involving the capture of technological and management know-how. As in the case of trade, also here there is an uneven impact across the European Union, with some member states achieving the European targets to transform into a knowledge-based economy while others stagnate or even decline. Defraigne shows how, against this background, the upgrading of China's technological knowledge - with the help of strategic acquisitions in Europe - threatens the future capacity of some of the European states.

Silvia Menegazzi's (Menegazzi 2017) article analyses another aspect of Chinese economic strategy, namely the efforts it has made to create new multilateral institutions for economic development and, in doing so, to contribute to a shift in the architecture of global finance. Chief among these efforts is the AIIB which-Menegazzi arguesshould not be seen only as an attempt by Beijing to promote its own narrative about economic governance, but is in fact part of a larger plan by China to become a more pro-active global leader in this field. Many European states have responded positively to this initiative and joined the AIIB, despite the conceptual and normative gaps that remain between the European and the Chinese models of economic development. The future challenge for the EU will be whether these gaps can be bridged through closer cooperation in institutions such as the AIIB.

\section{Conclusion}

The contributions to this special issue demonstrate the varied, multi-faceted and to some extent contradictory nature of EU-China relations. The two sides are in an evercloser embrace as far as their economic relations are concerned, yet remain distant and occasionally antagonistic with respect to security concerns or normative discourses. 
This makes it difficult to come to simple and straightforward conclusions-indeed, seeking to do might be misleading. The EU and China are, in some ways, close partners with common interests in a quickly changing world, yet, both sides also have fundamentally different world-views and distinct interests. To complicate matters further, the European side is often anything but united, with the divergence of member state perspectives on China increasing as the relationship becomes more important.

If there is one overarching message arising from the contributions to this volume, it is the growing complexity of this relationship and the many and diverse implications that this has for Europe. In terms of strategic choices, the EU is pre-occupied with the emergence of Russia as a threat for neighbouring countries on its Eastern borders and, more recently, with the fragmentation of the West that might follow BREXIT, and the election of Donald Trump. These developments threaten to weaken the unity of the European Union, giving China a strategic advantage to pursue its own agenda.

In the economic realm, Europe and China have developed a mutual dependency on trading with one another, and both remain champions of trade liberalization in an era in which this objective is becoming more difficult to advance. However, as the contributions to this issue show, the economic relations are anything but easy: not only are there a growing number of trade disputes as the Chinese economy develops into higher value-added goods that are the traditional domain of European manufacturers, but also Chinese investment in Europe - previously welcome in a capital-starved economy - is being viewed increasingly sceptically as the long-term implications of this strategic become perceptible.

In many of these accounts, the diverse impact of China's rise on Europe is evident-European states have different interests vis-à-vis China, depending on their political, economic and normative dispositions. Beyond that, the deeper engagement with China has the potential to exacerbate these differences, be it through the uneven economic impact of trade and investment relations, or due to the lack of agreement on normative principles or strategic priorities. It is clear that there is much at stake for Europe in its relations with the rising China-opportunities for greater cooperation, both bilaterally and in the context of old and new multilateral institutions. Yet, the rise of China also carries with it inherent risks for the European Union, not least in the way in which it may make it (even) more difficult to manage the relations with other global powers while maintaining a semblance of unity among the EU member states. Sweet grapes grow on thorny vines, as the Chinese saying goes, and it will be the challenge for Europe in future years to pick the grapes it seeks without getting hurt in the process.

Open Access This article is distributed under the terms of the Creative Commons Attribution 4.0 International License (http://creativecommons.org/licenses/by/4.0/), which permits unrestricted use, distribution, and reproduction in any medium, provided you give appropriate credit to the original author(s) and the source, provide a link to the Creative Commons license, and indicate if changes were made.

\section{References}

Anderlini, J (2015) China to become one of world's biggest overseas investors by 2020. Financial Times, 26 June. https://www.ft.com/content/5136953a-1b3d-11e5-8201-cbdb03d71480. Accessed 6 March 2017

BBC (2015) George Osborne on UK's "golden era" as China's "best partner in the West." 23 October. http://www.bbc.com/news/uk-34621254. Accessed 6 March 2017 
Bräuner O, Bromley M, Duchâtel M (2015) Western arms exports to China. SIPRI Policy Paper No. 43. https://www.sipri.org/sites/default/files/files/PP/SIPRIPP43.pdf. Accessed 6 March 2017

Brugier C (2017) The EU's trade strategy towards China: lessons for an effective turn. Asia Eur J. doi:10.1007 /s10308-017-0475-4

Christensen TJ (2015) The China challenge: shaping the choices of a rising power. W.W. Norton, New York

Christiansen T (2015) A liberal institutionalist perspective on China-EU relations. In: Wang J, Song W (eds) China, the European Union, and the international politics of global governance. Palgrave Macmillan, London, pp 29-50

Defraigne JC (2017) Chinese outward direct investments in Europe and the control of the global value chain. Asia Eur J. doi:10.1007/s10308-017-0476-3

Financial Times (2016) China tries chequebook diplomacy in Southeast Asia. 6 November. https://www.ft. com/content/abb35db2-a4cc-11e6-8b69-02899e8bd9d1. Accessed 6 March 2017

Freeman D (2017) Redistributing the EU-China economic relationship: the role of domestic change in China. Asia Eur J. doi:10.1007/s10308-017-0474-5

Helleiner E, Kirshner J (eds) (2014) The great wall of money: power and politics in China's international monetary relations. Cornell University Press, Ithaca

IMF (2016) IMF executive board concludes 2016 Article IV consultation with the People's Republic of China. https://www.imf.org/en/News/Articles/2016/08/11/20/37/PR16374-China-IMF-Executive-BoardConcludes-2016-Article-IV-Consultation. Accessed 6 March 2017

Jones C (2016) Chinese investment in Europe hits \$23bn record. Financial Times, 10 March. https://www.ft. com/content/c1155e72-e5e0-11e5-a09b-1f8b0d268c39. Accessed 6 March 2017

Kirchner EJ, Christiansen T, Dorussen H (eds) (2016) Security relations between China and the European Union: from convergence to cooperation? Cambridge University Press, Cambridge

Le Corre P, Pollack J (2017) China's rise: what about a transatlantic dialog? Asia Eur J. doi:10.1007/s10308017-0471-8

Maher R (2016a) The elusive EU-China strategic partnership. Int Aff 924:959-976. doi:10.1111/14682346.12659

Maher R (2016b) The rise of China and the future of the Atlantic alliance. Orbis 603:366-381. doi:10.1016/j. orbis.2016.05.003

Maher R (2017) Europe's response to China's rise: competing strategic visions. Asia Eur J. doi:10.1007 /s10308-017-0470-9

Maihold G (2014) Die BRICS-Bank - der Einstieg in eine neue Weltfinanzordnung, SWP-Aktuell, August 2014, Stiftung Wissenschaft und Politik, Berlin

Menegazzi S (2017) Global economic governance between China and the EU: the case of the Asian infrastructure investment bank. Asia Eur J. doi:10.1007/s10308-017-0477-2

Moore BR, Berreda RR (2016) China's PLA gets smarter (and bigger, faster, stronger). ForeignPolicy.com, 9 August. http://foreignpolicy.com/2016/08/09/china-military-modernization-college-degrees-plaeducation/. Accessed 6 March 2017

Nicholson P (2015) The Beijing-Berlin Connection. ForeignAffairscom, 13 August. https://www. foreignaffairs.com/articles/china/2015-08-13/beijing-berlin-connection. Accessed 6 March 2017

Office of the Secretary of Defense (2015) Military and security developments involving the People's Republic of China 2015, Annual Report to Congress. http://www.defense.gov/Portals/1/Documents/pubs/2015 China_Military_Power_Report.pdf. Accessed 6 March 2017

Reilly J (2017) China's economic statecraft in Europe. Asia Eur J. doi:10.1007/s10308-017-0473-6

Renard T (2015) The Asian infrastructure investment Bank (AIIB): China's new multilateralism and the erosion of the West, Egmont security brief no. 63. Egmont Institute, Brussels

Shambaugh D (2013) China goes global: the partial power. Oxford University Press, New York

Sieren F (2014) Eastern Europe as Beijing's gateway. Deutsche Welle, 15 December. http://www.dw. com/en/eastern-europe-as-beijings-gateway/a-18133170. Accessed 6 March 2017

Sverdrup-Thygeson B (2017) The bear and the EU-China-US triangle: transatlantic and Russian influences on EU's "pivot to Asia". Asia Eur J. doi:10.1007/s10308-017-0472-7

Xi J (2017) Speech at the World Economic Forum. Davos, 17 January. https://www.weforum.org/agenda/2017 /01/full-text-of-xi-jinping-keynote-at-the-world-economic-forum. Accessed 6 March 2017 